\title{
The influence of common property rights on forest management policy: a case study in Sardinia region, Italy
}

\author{
Alessandro Paletto ${ }^{1^{*}}$, Isabella De $\mathrm{Meo}^{2}$ and Fabrizio Ferretti ${ }^{3}$
}

Paletto, A., De Meo, I., Ferretti, F. 2012. The influence of common property rights on forest management policy: a case study in Sardinia region, Italy. - Forestry Studies | Metsanduslikud Uurimused 56, 16-26. ISSN 1406-9954.

\begin{abstract}
The property rights and the type of ownership (private owners, public domain and commons) are two fundamental concepts in relationship to the local development and to the social and environmental sustainability. Common forests were established in Europe since the Middle Ages, but over the centuries the importance of commons changed in parallel with economic and social changes. In recent decades, the scientific debate focused on the forest management efficiency and sustainability of this type of ownership in comparison to the public and private property. In Italy common forests have a long tradition with substantial differences in the result of historical evolution in various regions. In Sardinia region the private forests are $377.297 \mathrm{ha}$, the public forests are $201.324 \mathrm{ha}$, while around 120.000 ha are commons. The respect of the common rights changed in the different historical periods. Today, the common lands are managed directly by municipalities or indirectly through third parties, in both cases the involvement of members of community is very low. The main objective of the paper is to analyse forest management differences in public institutions with and without common property rights. To achieve the objective of the research the forest management preferences of community members and managers were evaluated and compared. The analysis was realized through the use of the principal-agent model and it has been tested in a case study in Sardinia region (Arci-Grighine district). The analysis of the results showed that the categories of actors considered (members of community, municipalities and managers) have a marked productive profile, but municipalities manage forests perceiving a moderate multifunctionality. Moreover, the representatives of the municipalities pay more attention to the interests of the collectivity in comparison to the external managers. They also attribute high importance to environmental and social forest functions.
\end{abstract}

Key words: common forests, property rights, forest management, principal-agent model, Arci-Grighine district (Sardinia-Italy).

Authors' addresses: ${ }^{1}$ Consiglio per la Ricerca e la sperimentazione in Agricoltura - Forest Monitoring and Planning Research Unit (CRA-MPF), p.za Nicolini 6, 38123 Villazzano di Trento, Italy; ${ }^{2}$ Consiglio per la Ricerca e la sperimentazione in Agricoltura - Agrobiology and Pedology Centre (CRA-ABP), p.za Massimo D'Azeglio 30, 50121 Firenze, Italy; ${ }^{3}$ Consiglio per la Ricerca e la sperimentazione in Agricoltura - Apennine Forestry Research Unit (CRA-SFA), via Bellini 8, 86170 Isernia, Italy; ${ }^{*}$-mail: alessandro.paletto@entecra.it

\section{Introduction}

Common forests in Europe have a long historical tradition, dating back to Middle Ages when rural peoples depended on forests for a wide range of products essential to their livelihoods (firewood, timber, fodder, edible fruits) (Koch \& Kennedy, 1991). The social and economical transformations of the last 300 years have profoundly changed the relationship between communities and forests; the main change was the shift from traditional agricultural society to modernindustrial society (Notaro \& Paletto, 2011). 
During the $17^{\text {th }}$ century, the liberal ideas of progress and modernization had a profound effect both on land ownership and on access to natural resources. In this historical period, the theory of possessions elaborated by John Locke spreads in all disciplines, by considering property as a constitutive part of a person. The individual ownership is considered an essential aspect of economic development and innovation diffusion (Holmgren et al., 2010) and the assumption of this theory is that private property provides individual owners with considerable incentives to use resources efficiently and sustainably. In fact in such conditions the owner is able to monopolize the benefits of management (Tucker, 1999; Agrawal \& Gibson, 1999). Common property is considered an open access resource and consequently it leads inevitably to a "tragedy of the commons" (Hardin, 1968). The consequence of the success of liberal ideas is that many of the common forests were enclosed and privatized or were subject to different types of public and commercial forest management. In Western Europe, the growth of economic well-being, the high level of education and the greater availability of leisure time led to a second social change culminated in the mid 60s and 70s of the $20^{\text {th }}$ century. The change is summarized in the transition from modern-industrial society to the postmodern society and in the consequent change in social value systems (from materialistic values to post-materialist values) (Inglehart, 1977).

As a consequence of these changes, the interest of the scientific and political communities around the common-pool resources has increased in the last decades (Laerhoven \& Ostrom, 2007), particularly with regard to the issue of natural resource management. This interest is related to the role for local development and survival of these traditional institutions (Holmgren et al., 2004) and to the contrasts with the precepts of the classical economists who emphasized the importance of private property in the economic process. Other authors demonstrate that the presence of common property allows a more efficient management of natural resources than private and state property (Poteete \& Ostrom, 2008). The efficiency of management refers not only to ecological aspects such as a greater focus on sustainability, but especially to the economic and social outcomes (Coleman, 2011). Moreover, the common property ensures a more equitable distribution of benefits, but the results of the management are also conditioned by the managing organization (governments, communal groups, cooperatives, voluntary associations and private individuals or firms) (Ostrom, 2003).

In Italy the term common property rights is used to identify the rights of common use (dominium utile) of land to the single members of communities (uti cives), to the hamlet (demani civici) or to the associations and agrarian universities (domini collettivi). Normally, common property rights refer to legal models that regulate the use of the land and organize the use of their territory in order to ensure collective access to their natural resources (Cacciarru, 2009). In the Italian Alpine regions there were the alpine village communities known as regole, vicinie, patriziati, and comunalie that administered and managed common forests and pastures (Merlo, 1995). These traditional institutions were structured with representatives (president and managerial board) elected by the members of community (householders). In Southern Italy, common lands (called demanio universale) were used by local families and administered by the council of households (Universitas civium). After the National Law № 1766/ 1925, the original common property rights have been modified and in many cases devoid of meaning. Presently, common land continues to be a collective good, but municipalities' citizens can use the land according to rules and regulations stated by local municipal governments. In other words, the right of use for the members of community is assured from the legislative 
point of view, but the manager and administrator of the common-pool resource is a public organization.

The main objective of the paper is to analyse the differences in the management of common forests among various categories of actors. To achieve the objective the management preferences of community members and managers were evaluated and compared. The research is conducted in a district in Sardinia region (Arci-Grighine district, Oristano province) where the tradition of common forests and pastures is still alive and active.

\section{Material and Methods}

\section{Common forests in Sardinia}

Considering the national level, the Italian legislation specifies the competences of different public administrations (regions, provinces, municipalities) in matter of common property rights (usi civici). A specific organization, the Amministrazione separata dei beni di uso civico frazionale (ASBUC institutional organization of community of village), has the purpose of management of common forests and pastures. At regional level, the Regional Law of Sardinia № 12/1994 established that the manager of common land is the municipality or the hamlet and that the management is carried out through a special regulation act (articles no. 11 and 12). Hamlet is part of municipality territory characterized by an inhabited place or scattered houses linked to the inhabited place. However, the municipality may delegate the management of common land to special categories of actors (article no. 16).

In Sardinia region the common property rights is peculiar in comparison with other Italian regions and it comprises the ademprivio, cussorgia and orzaline rights. These three traditional rights are similar, but the first is a right of the community, while the second and the third are rights of single persons (i.e. shepherds or farmers). In particular, the ademprivio includes common pas- ture (right to pasture cattles or other animals on common land) and estovers or bote (right to take sufficient wood for the commoner's household or agricultural needs) (Scotti \& Cadoni, 2007). Cussorgia and orzaline represent, respectively, the right for a single member of community to pasture animals (cussorgia rights) or to cultivate barley (orzaline rights) on common lands, paying an annual rent.

Historically, the diffusion of the rights on common land is documented since the Aragon period (XIV century), but the origin of the ademprivio is much older. The origin of this right is linked to the communalia and the communia, and it is datable to the Roman domination period. Instead, the cussorgia is a more recent right born in the Middle Ages. The feudatory granted the exclusive right to use a forest or a pasture to the feudal vassal in exchange of an annual rent. The cussorgiale (person with the right of cussorgia) was often in contrast with the others ademprivisti (persons of the community of village with the right of ademprivio) because his right prevents other members of the community the free exercise of the rights of ademprivio. The orzaline right is similar to the cussorgia right, but it concerns the possibility for a single person to cultivate a common land in an individual way.

During the Aragon period the Prammatiche regie were in force, a collection of laws adopted by King Philip IV in 1633 and elaborated by lawyer Francesco de Vito. The Prammatiche regie establish some limitations to the common land rights: for example, commoners do not have the right to sell or alienate goods or benefits from the common (Scotti \& Cadoni, 2007).

In the middle of the $19^{\text {th }}$ century - with the diffusion of modern economic theories on the great efficiency of the private property - legislators started a series of attempts to abolish the ademprivio and cussorgia rights. In spite of these political attempts, the ademprivio and cussorgia rights are still active. 


\section{Study area}

The Arci-Grighine district (39 $42^{\prime} 7^{\prime \prime}$ North; $8^{\circ} 42^{\prime} 4^{\prime \prime}$ East) is located in Central-Eastern Sardinia. The Arci-Grighine district has a total surface of 55.183 ha, corresponding to the $2.3 \%$ of the Sardinia island surface. The district comprises 21 municipalities with a population of 26.207 and a density of about 0.47 persons/ha (2001 Census). The rural sector plays quite an important role in the economic structure of the district (31\% of the total amount of district enterprises), but more important is the industrial sector with $45 \%$ of the enterprises.

According to Regional Forest Plan (2007) realized by Sardinia Region, forest surface covers $51.2 \%$ (28.253 ha) of the territory of Arci-Grighine; other land uses are agricultural land (33.9\%), grassland $(10.0 \%)$ and agro-pastoral land (4.9\%). There are four main forest types: broadleaf forests (Quercus spp. dominant forests) $43.2 \%$, Mediterranean forests (Erico

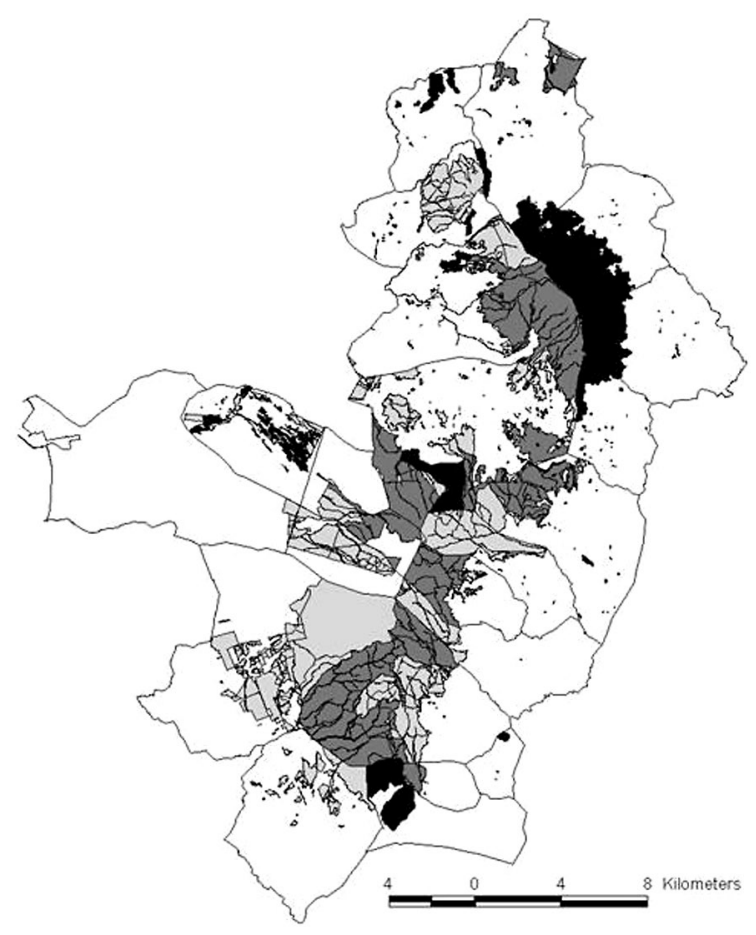

arboreae-Arbutetum unedonis and Pistacio lentisci-Calicotometum villosae associations) 39.6\%, evergreen forests (Quercus ilex and Quercus suber dominant forests) and mixed forests $0.6 \%$.

Considering the ownership, private forests represent $44 \%$ (12.308 ha), common forests the $45 \%$ (12.834 ha) and public forests the remaining 11\% (3.126 ha). Common forests, as well as public forests, are managed by municipalities or, through delegation, by public companies (special categories of actors considered by article no. 16 of Regional Law of Sardinia № 12/1994). In the Arci-Grighine there are two main categories of delegated managers: Ente Foreste Sardinia (public organization in charge of forest planning and management of municipalities' territory) and local cooperatives of land management.

According to the principles established with the Regional Law the common property rights are active in $39 \%$ of public forests (6.290 ha), while in $41 \%$ these rights are suspended (6.544 ha). Therefore, in the district, forest management depends on the typology of the area where forests are located (Fig. 1): (1) area without common land rights (public and/or private forests), (2) area with common land rights temporarily suspended according to the Regional Law № 12/1994, and (3) area with common land rights. On the whole, six municipalities own exclusively forests without common rights, other five municipalities own exclusively forests with common rights and the other ten municipalities are in intermediate situations with respect to these extremes (Fig. 2).

Figure 1. Common land rights distribution in ArciGrighine district.

Area with common land rights

Area with common rights temporarily suspended

Area without common land rights 


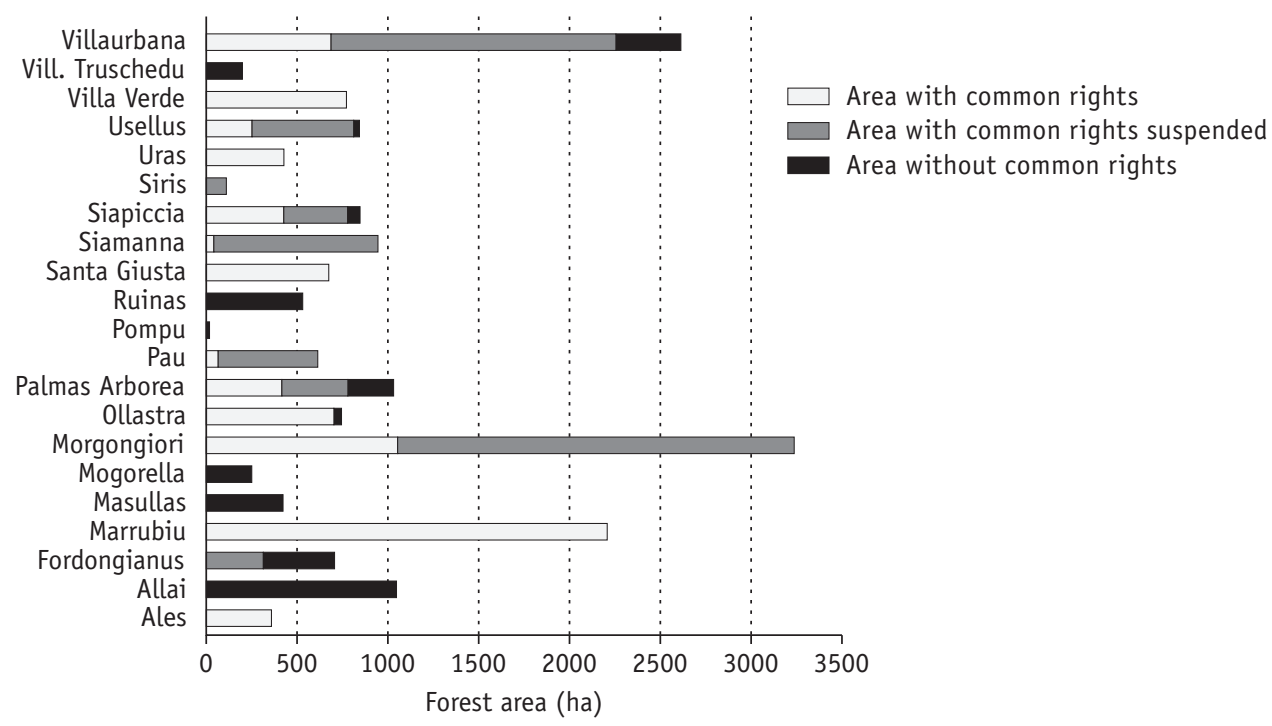

Figure 2. Forests distribution by municipality in relationship to the common land rights.

\section{Research framework}

The management of common forests in the district can be analyzed through the principal-agent model, with special emphasis on the application to the public administrations (Fukuyama, 1995; Miller \& Whitford, 2002). According to Shapiro (1987), in principal-agent relationships, principals - for whatever reason or state of mind - invest resources, authority or responsibility on another (agent) to act on their behalf for some uncertain future return.

In the Arci-Grighine district, we have highlighted three levels of actors involved (Fig. 3) in the management of forests. The first level includes the principals (members of community); the second level includes the replacement of principals (municipalities), while at the third level there are the agents (managers such as public companies or cooperatives). In comparison with the two level model, the three level model is more complex and potentially inefficient. The inefficiency can be linked to an increased possibility of misunderstanding between agent and replacement of principal or between replacement of principal and principal. In this paper divergences and misunderstandings in management among principal, replacement of principal and agent are analyzed. From a political point of view this kind of analysis is useful in order to highlight managerial divergences between representatives and represented, but also between different levels of representatives.

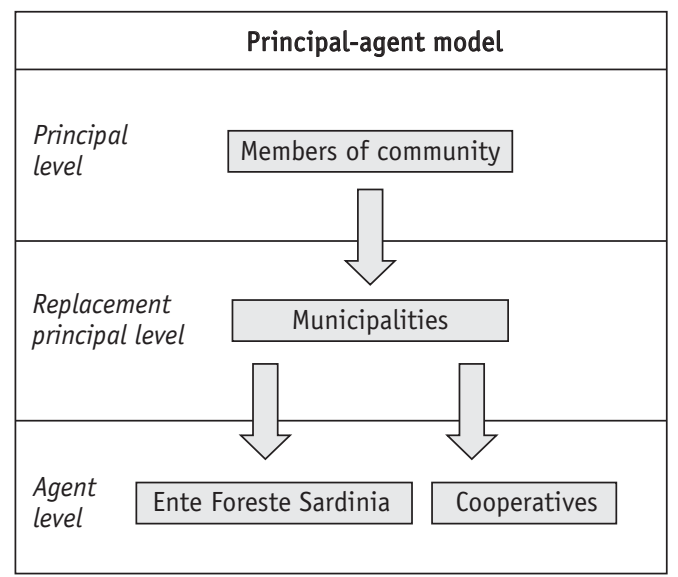

Figure 3. Application of the principal-agent model to analyse the relationships in the forest management. 
In order to describe comparison and contrast related to managerial objectives between the principal and the replacement or the agent, a specific questionnaire was submitted to the representatives of municipalities, and to a sample of forest managers and members of community. The questionnaire - subdivided into thematic sections was submitted by face-to-face interviews. In order to provide simple interviews, a close-question format was prepared. As a matter of fact, close-ended questions are easier to analyze and permit statistical calculations. In this paper, only the thematic section focusing on the rural and forestry development strategies is considered; in particular three questions are deeply analized (Table 1): the first question (Q1) on the relative importance of forest functions, the second question $(\mathrm{Q} 2)$ on the strategies of rural development of the district and the third question (Q3) on the quality of relationship among the group of actors.

The questionnaire was submitted to 44 members of community (principal), to 21 representatives of municipalities (replacement principal) and to 13 forest managers (11 managers of different forest stations of Ente Foreste Sardinia and 2 local coopera- tives). The sample of members of community was extracted from individual actors belonging to the agro-forestry sector (i.e. forest and wood enterprises, forest owners, farmers and shepherds).

The relevance of forest multifunctionality in the district, which represents one of the main objective for forest management, is evaluated through this specific question: "What are the most important forest functions in Arci-Grighine district?". In order to evidence actors' preferences, interviewees were asked to assess the importance of each single forest function in a scale of four options $(4=$ high importance, $3=$ medium importance, 2 = low importance, 1 = very low importance). The list of forest functions - individuated by both local technicians and researchers - was presented to the interviewees in a close answer form, without the possibility of adding any additional function. The individual preferences attributed by the actors to each forest function were elaborated by sorting them according to a list of priorities.

In order to integrate information about forest multifunctionality management, actors were asked to indicate which are the most appropriate forest strategies to

Table 1. Questions selected to analyze common properties management in Arci-Grighine district.

\begin{tabular}{|c|c|}
\hline Fuelwood & Hydrogeological protection \\
\hline Industrial roundwood & Gaming \\
\hline Grazing & Tourism \\
\hline Cork production & Landscape \\
\hline Beekeeping & Habitat conservation \\
\hline Myrtle production & \\
\hline
\end{tabular}

Q2 Which interventions on forests contribute to the economic development of Arci-Grighine district? Development of forest-wood chain Improvement of forest roads and tracks Improvement of tourist facilities Implementation of environmental protection activities Intensify cooperation between the municipalities

Q3 Which is the quality of relationship with the other actors?

Municipalities

Ente Foreste Sardinia

Local cooperatives 
promote the economic development of the district with the specific question: "Which interventions on forests contribute to the economic development of Arci-Grighine district?". The question was formulated to allow the interviewees to rate the five strategies on a 1 to 5 priority scale (1 being top strategy and 5 being low strategy).

A third question (Q3) investigated the quality of relationship among the groups of actors involved in the principal-agent model. The interviewees were asked to assess the quality of relationship with the other actors in a scale of four options: $4=$ good level of collaboration, $3=$ medium level of collaboration, 2 = low level of collaboration, 1 = very low level of collaboration. Moreover, only municipalities that delegate the forest management to a third party expressed an opinion on managers (Ente Foreste Sardinia and local cooperatives).

Data collected by questionnaire were processed using mean values and standard deviation (SD), to highlight the importance of the various forest functions and rural development strategies for each group of actors. The Chi-square test $\left(\chi^{2}\right)$ was applied to test the association between the three groups of actor relating to the importance given to forest functions. The level of significance was set at $p<0.1$. The null hypothesis assumes that there are no differences among the groups regarding the importance given to each forest functions whereas the alternative hypothesis assumes that there is a difference. The Chi-square test results could therefore be interpreted to point out differences and divergences between actors regarding forest management strategies. The recognition and the identification of these differences can support decison makers in avoiding conflicts when addressing future forest management.

\section{Results and Discussion}

Considering the importance given to diverse forest functions, the comparison among the three groups of respondents shows that there are not important differences in the priority order of functions (Table 2). Gaming and fuelwood are the most important functions for the three groups of respondents. In order to understand which functions to take into account in the future forest management plan, only functions with an average score greater than 3.0 were considered. Using this hypothesis, for the three groups of actors it is possible to observe differences in the range of priorities (Table 3). The political agenda of the principal (members of community) is restricted to only three functions (gaming, fuelwood and landscape conservation), while the replacement principal (municipalities) considers three func-

Table 2. Mean value for the forest functions assigned by the three categories of actors.

\begin{tabular}{lcccccc}
\hline Forest functions & \multicolumn{2}{c}{$\begin{array}{c}\text { Members of community } \\
(\mathrm{N}=44)\end{array}$} & \multicolumn{2}{c}{$\begin{array}{c}\text { Representatives of munici- } \\
\text { palities }(\mathrm{N}=21)\end{array}$} & \multicolumn{2}{c}{$\begin{array}{c}\text { Managers } \\
(\mathrm{N}=13)\end{array}$} \\
& Mean & SD & Mean & SD & Mean & SD \\
\hline Gaming & 3.9 & 0.4 & 4.0 & 0.0 & 3.8 & 0.4 \\
Fuelwood & 3.6 & 0.6 & 3.7 & 0.6 & 3.8 & 0.4 \\
Landscape & 3.4 & 0.8 & 3.6 & 0.5 & 2.8 & 1.0 \\
Habitat conservation & 2.9 & 1.3 & 3.2 & 0.8 & 3.2 & 0.8 \\
Myrtle production & 2.9 & 1.0 & 3.1 & 0.9 & 3.2 & 0.8 \\
Tourism & 2.4 & 1.2 & 3.1 & 0.8 & 2.4 & 0.8 \\
Grazing & 2.3 & 1.1 & 2.6 & 0.9 & 2.8 & 0.7 \\
Cork production & 2.1 & 1.0 & 2.2 & 1.0 & 2.2 & 1.0 \\
Beekeeping & 2.0 & 1.2 & 2.2 & 0.9 & 2.3 & 0.8 \\
Hydrogeological protection & 1.8 & 1.5 & 2.6 & 1.2 & 2.2 & 1.0 \\
Industrial roundwood & 1.1 & 0.5 & 0.9 & 0.3 & 1.0 & 0.0 \\
\hline
\end{tabular}


Table 3. Forest functions included in the political agenda of the different actors.

\begin{tabular}{|c|c|c|c|}
\hline & $\begin{array}{l}\text { Members of } \\
\text { community }\end{array}$ & $\begin{array}{l}\text { Representatives of } \\
\text { municipalities }\end{array}$ & Managers \\
\hline $\begin{array}{l}\text { Forest functions } \\
\text { to be considered } \\
\text { in the future } \\
\text { forest plan }\end{array}$ & $\begin{array}{l}\text { Gaming } \\
\text { Fuelwood } \\
\text { Landscape }\end{array}$ & $\begin{array}{c}\text { Gaming } \\
\text { Fuelwood } \\
\text { Landscape } \\
\text { Habitat conservation } \\
\text { Tourism } \\
\text { Myrtle production }\end{array}$ & $\begin{array}{c}\text { Gaming } \\
\text { Fuelwood } \\
\text { Habitat conservation } \\
\text { Myrtle production }\end{array}$ \\
\hline
\end{tabular}

Table 4. Importance of local development strategies linked to the forestry sector for the groups of actors.

\begin{tabular}{lcccccc}
\hline Local development strategies & \multicolumn{2}{c}{$\begin{array}{c}\text { Members of com- } \\
\text { munity }(\mathrm{N}=44)\end{array}$} & $\begin{array}{c}\text { Representatives of } \\
\text { municipalities }(\mathrm{N}=21)\end{array}$ & \multicolumn{2}{c}{$\begin{array}{c}\text { Managers } \\
(\mathrm{N}=13)\end{array}$} \\
\cline { 2 - 7 } & Mean & SD & Mean & SD & Mean & $S D$ \\
\hline Development of forest-wood chain & 2.4 & 1.6 & 2.4 & 1.4 & 2.2 & 1.4 \\
Improvement of forest roads and tracks & 3.3 & 1.6 & 2.7 & 1.5 & 3.5 & 1.4 \\
Improvement of tourist facilities & 3.3 & 1.2 & 4.0 & 1.0 & 3.5 & 1.2 \\
$\begin{array}{l}\text { Implementation of environmental activities } \\
\text { and habitat protection }\end{array}$ & 3.0 & 1.5 & 3.0 & 1.3 & 3.2 & 1.4 \\
$\begin{array}{l}\text { Intensification of cooperation between the } \\
\text { municipalities }\end{array}$ & 2.7 & 1.3 & 3.0 & 1.4 & 2.5 & 1.4 \\
\hline
\end{tabular}

tions in addition to those took into account by the community (habitat conservation, tourism and recreation in forest, and myrtle production).

The preferences expressed by the municipalities move from economic to environmental and social functions and seem to indicate that a management oriented to perceive a moderate multifunctionality is considered as a priority.

The results of the Chi-square $\left(\chi^{2}\right)$ test showed significant differences $(p<0.1)$ among the three groups for these functions: hydrogeological protection (observed value $=14.251$, critical value $=10.645, p$-value $=$ 0.027), landscape conservation (observed value $=11.171$, critical value $=10.645, p$ value $=0.083$ ) and grazing (observed value $=12.088$, critical value $=10.645, p$-value $=$ $0.060)$.

The members of community consider the grazing activities and the protective function of forest less important in comparison to the vision of the managers. Probably these differences are linked to the recent economic marginalization of the grazing activities in the study area; municipalities and managers consider the economic improvement of this activity an important element for the revitalization of the ArciGrighine district. The hydrogeological protection is a technical function of forest, for this reason the members of community do not have a comprehensive perception of the relevance of this service.

Managers show an intermediate situation, characterized by four functions in the political agenda. Considering that three of these are economic functions, it seems to indicate that external managers have an economic oriented approach to forest management.

The analysis of responses regarding forest management strategies to improve the progress of local economy shows (Table 4) that the improvement of tourist facilities is the most important strategy for all actors (3.5 for the managers, 4.0 for the representatives of municipalities and 3.3 for the members of community). On the contrary - 
Table 5. Matrix of relationship among the actors involved in the principal-agent model.

\begin{tabular}{lcc}
\hline & Municipalities & Managers (Ente Foreste Sardinia) \\
\hline Members of community & 2.8 & 3.0 \\
Municipalities & 2.5 & 1.9 \\
Managers & 2.9 & 3.0 \\
\hline
\end{tabular}

considering the total range of strategies results indicate that managers and members of community focus on the same three strategies: the improvement of tourist facilities, the implementation of environmental activities and the improvement of forest roads and tracks. Vice versa representatives of municipalities identify the intensification of their cooperation as the third main strategy.

In order to test the differences among the three groups of actors regarding forest management strategies, the Chi-square test $\left(\chi^{2}\right)$ was applied. The results obtained did not show a statistical difference $(p<0.1)$.

In the last part of questionnaire, the quality of relationship among the three actors involved in the principal-agent model is analyzed. The results are presented in a matrix of relationship with respondents

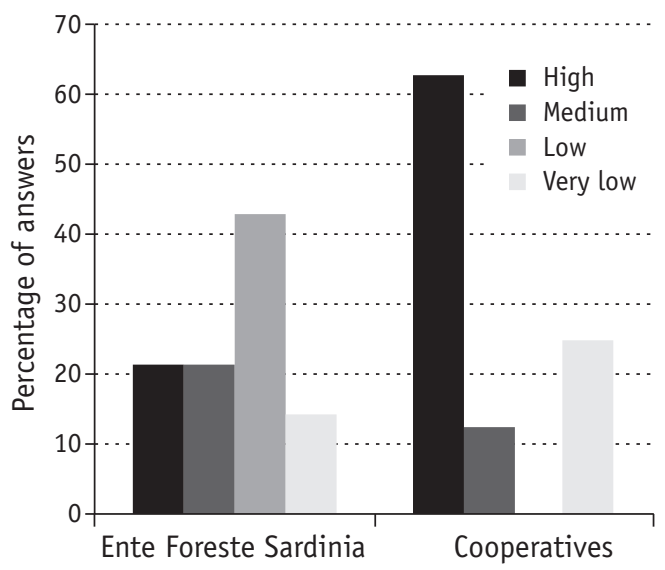

Figure 4. Level of satisfaction related to the strategies of managers (agents) expressed by municipalities. in columns and the actors indicated by respondents in the lines (Table 5). The members of community have a good and collaborative relationship both with municipalities (2.8) and with Ente Foreste Sardinia (3.0). The lowest value of collaboration is between municipalities and forest managers; this fact seems to indicate that management is more efficient when it is not delegated but directly carried out by the municipalities.

Finally, Figure 4 illustrates the level of satisfaction of municipalities representatives with regard to the management carried out by Ente Foreste Sardinia and cooperatives. The level of satisfaction is on the average higher in relation to the style of management of cooperatives (mean value $=3.1$ ) in comparison with the forest management of Ente Foreste Sardinia (mean value $=2.5$ ).

This is probably related to management strategies convergences between cooperatives and municipalities. Cooperatives, such as many municipalities, have an economic approach to forest multifunctionality aimed at increasing fuelwood (also in order to satisfy the common land rights) and cork production. On the contrary, Ente Foreste Sardinia has an ecological approach to forest multifunctionality, aimed at encouraging non-monetary forest functions.

\section{Conclusions}

With regard to the method of investigation, questionnaire was an efficacious tool in order to collect objective answers. This metod permitted to obtain information and to catch facets of common forests issue. In such a way it was possible to deeply 
analyze the questions and to relate the obtained information to the governance of the district, with the aim of pointing out if the top down approach to decision making process is of success in the management of common forests.

In relation to the main objective of the paper, some considerations emerged from the investigation carried out in the district.

Considering forest management differences, the research evidences that all the categories of actors have a marked productive profile, but municipalities manage forests perceiving a moderate multifunctionality. Probably it can be tied to the fact that municipality, respect to external manager and community, pay more attention to the interests of the collectivity. When municipalities directly manage forests, more attention is given to environmental and social functions, as evidenced in the political agenda.

In the light of the situation of Sardinia region, but also according to other Italian situations, a reflection merge around gaming, this resulted the most important function for the three groups of respondents. Gaming is a productive function but in the context of Arci-Grighine has a social role, because people practice this activity principally for recreation.

The relevance given to the improvment of tourist facilities and environmental activities by all the categories seems to indicate that the development of management strategies oriented to multifunctionality is a prority in the vision of all the actors. The expression of interest toward the intensification of cooperation between the municipalities can be read in the light of municipalities' interest in strengthening the whole forest sector of the territory.

The values showed in the matrix of relationship among the actors involved in the model can be interpreted once more according to the fact that all actors are oriented, more or less, to a productive management of forest. This convergence explains the fact that no remarkable differences are observed in the level of satisfaction of the three groups in relation to other actor's management.

The principal-agent model is particularly suited to investigate the relationships between actors linked by a hierarchical relationship. In this paper, the application of the model allowed to highlight comparisons and contrasts between owners and managers in order to better address the future forest management. As written before, in Arci-Grighine, similarities are more important then differences but it was important to verify them. Furthermore it was relevant to establish that municipalities have a wider point of view concerning forest functions. This approach, using only three simple questions, was very easy to apply and fruitful to outline management differences and similarities.

Acknowledgments. Funding for this project was provided by Regione Autonoma della Sardegna. The authors contributed equally to this work.

\section{References}

Agrawal, A., Gibson, C. 1999. Enchantment and Disenchantment: The Role of Community in Natural Resource Conservation. - World development, 27(4), 629-649.

Cacciarru, A. 2009. Land use patterns and access to resources: the usi civici in Ogliastra (Sardinia). Archivio Scialoja-Bolla, 1, 143-161.

Coleman, E.A. 2011. Common property rights, adaptive capacity, and response to forest disturbance. Global Environmental Change, 21, 855-865.

Fukuyama, F. 1995. Trust: The social virtues and the creation of prosperity. New York, Free Press. 480 pp.

Hardin, G. 1968. The tragedy of the commons. - Science, 162, 1243-1248.

Holmgren, E., Lidestav, G., Kempe, G. 2004. Forest Condition and Management in Swedish Forest Commons. - Small-scale Forest Economics, Management and Policy, 3(3), 453-468.

Holmgren, E., Keskitalo, E.C.H., Lidestav, G. 2010. Swedish forest commons - A matter of governance? - Forest Policy and Economics, 12, 423-431. 
Koch, N.E., Kennedy, J.J. 1991. Multiple-use Forestry for Social Values. - Ambio, 7, 330-333.

Inglehart, R. 1977. The silent revolution: Changing values and political styles among Western publics. Princeton, Princeton University Press. 482 pp.

Laerhoven, F., Ostrom, E. 2007. Traditions and Trends in the Study of the Commons. - International Journal of the Commons, 1(1), 3-28.

Merlo, M. 1995. Common property forest management in northern Italy: a historical and socio-economic profile. - Unasylva, 46(180), 58-63.

Miller, G.J., Whitford, A.B. 2002. Trust and incentives in principal-agent negotiations. - Journal of Theoretical Politics, 14(2), 231-267.

Notaro, S., Paletto, A. 2011. Links between Mountain Communities and Environmental Services in the Italian Alps. - Sociologia Ruralis, 51(2), 137-157.

Ostrom, E. 2003. How types of goods and property rights jointly affect collective action. - Journal of Theoretical Politics, 15(3), 239-270.
Poteete, A.R., Ostrom, E. 2008. Fifteen years of empirical research on collective action in natural resource management: struggling to build large-n databases based on qualitative research. - World Development, 36(1), 176-195.

Scotti, R. Cadoni, M. 2007. A historical analysis of traditional common forest planning and management in Seneghe, Sardinia - Lessons for sustainable development. - Forest Ecology and Management, 249, 116-124.

Shapiro, S.P. 1987. The social control of impersonal trust. - American Journal of Sociology, 93(3), 623-658.

Tucker, C.M. 1999. Private versus common property forests: forest conditions and tenure in a Honduran Community. - Human ecology, 27(2), 201-230.

Received February 13, 2012, revised March 23, 2012, accepted March 30, 2012 